Nizath S.M. \& Karunaratne R.A.I.C.

Wayamba Journal of Management 12 (2)

\title{
A Gender Role Perspective on the Impact of Work from Home on Work-Life Balance: Employees' Experience During Covid -19 Pandemic in Sri Lanka
}

\author{
S.M. Nizath ${ }^{1} \&$ R.A.I.C. Karunaratne ${ }^{2}$ \\ 1,2 Department of Human Resource Management \\ Faculty of Commerce and Management Studies \\ University of Kelaniya, \\ SRI LANKA \\ nizath9727@gmail.com ${ }^{1}$, ishankac@kln.ac.lk ${ }^{2}$
}

\begin{abstract}
The covid-19 pandemic has impacted every aspect of human life. Many employees start work from home during this pandemic situation, which disturbs employees' everyday work and non-work schedules as it is an unusual practice for some employees. However, there are limited studies which examine the effect of work from home on work-life balance. Based upon work life border theory and crossover spillover theories, the current study attempted to examine the effect of work from home on work-life balance and to examine the moderating role of gender. Using a structured questionnaire, data were collected from 301 employees who started work from home during the Covid-19 pandemic. This study is cross-section nature, as data collection was limited to one point in time. Based upon the extant literature, we developed two hypotheses which proposed the direct effect of work from home on work life balance and the moderating effect of gender on the proposed relationship. The data were analyzed using regression. The results showed that work from home significantly and negatively influence on work-life balance. However, moderating effect of gender was insignificant. Thus, work from home negatively influence on employee work life balance irrespective of their gender. The results of this study inform the literature employees face difficulties of managing their work and non-work life when the there is no clear boarders between work and non-work.
\end{abstract}

Keywords-: Covid-19 Pandemic, Employee Gender, Work-Life Balance, Work from Home

\section{INTRODUCTION}

In recent years, there has been an increasing interest in how employees manage their family life while engaging ${ }^{i}$ in work. Moreover, a great deal of research attempted to examine the interaction between work and family domains (Humphries, McDermott, Creese, Matthews, Conway, Byrne; 2020; Koon, 2020; Lazarova, Westman, \& Shaffer, 2010). Work-life balance determines how an employee 
shares the available time and the effort between family responsibilities and work requirements. Hill, Hawkins, Ferris, and Weitzman (2001) refer to work-life balance as the extent to which an employee can simultaneously balance temporal, emotional, and behavioral demands of both paid work and family responsibilities (as cited in Darcy \& McCarthy, 2007). In particular, there have been observations that the degree of imbalance between family life and work has increased gradually in recent years because the work and family roles have become increasingly intertwined, and the balance between work and life is marked as the struggle facing by the employees on a daily basis in all over the world (Karkoulian, Srour \& Sinan, 2016).

The increased focus on work-life balance makes organizations plan and implement work-life policies (Sanchez, Perez, Jimenz \& Garces, 2018). Flexible work policy can be referred into different arrangements (Choo, Desa \& Asaari, 2016; Oludayo, Salau, Falola, Atolagbe, Ogueyungbo \& Fatogun, 2019; Swaty \& Pahwa, 2020). Even though, several flexible work policies exist, these days' work from home (WFH) or home-based working has been promoted and motivated by the employers as a way of performing the task, duties, and responsibilities with considering the nature and characteristics of their job to limit the further spread of Covid-19. The so-called global pandemic seriously affects all aspects of human lives, irrespective of where they are located.

All the entities are scrambling to respond to the Covid-19. Every firm believes that employees are its most valuable resource and is committed to providing a healthy and safe working environment for all its associates. Accordingly, to prioritize the employees' safety within times of crisis, the companies instructed their employees to carry out work duties from their homes while optimizing productivity. Thus, work from home is one initiative that has been implemented and motivated to navigate work responsibilities while staying safe and resilient. The organizations find ease with implementing work from home under Flexi work policy with the expansion of residential high-speed internet and advances in telecommunication and network tools and systems in recent years.

However, working under the schedule of working from home may face many challenges with balancing family and work demands effectively as the demands of work and family roles are mutually incompatible. As crossover and spillover theory (Bakker \& Demerouti, 2009; Westman, 2001) explained, stress, strain, emotions, or experience can transfer from one domain to another domain; work domain to family domain vis-à-vis. Moreover, extant research has found that stress from the work domain transmits to the family domain., i.e., spillover effect 
(Bakker \& Demerouti, 2009; Westman, 2001; Westman \& Vinokur, 1998). The transmission of stress from one person to another person in a close relationship through an emotional contagion process called crossover effect (Bakker, Demerouti, \& Burke, 2009; Westman, 2001; Westman \& Vinokur, 1998). However, most extant studies are based on a sample from typical employees (work at the office), and less attention has been paid to worklife balance when employees are working from home. Unlike typical situations, during the Covid-19 period, all family members may stay home, and much interaction can happen among family members. Thus, this study focuses on examining the effect of work from home on work-life balance, particularly during the Covid-19 pandemic.

Sri Lanka as a collectivistic culture still the life revolves around the family. Thus, the family connectedness is paramount in their lives. Prior research on work life balance has shown the strong relationship between work-life balance and work and non-work outcomes. For example, in their study Nilashini \& Sajeevanie (2018) found a strong relationship between work life balance and employee performance. As another example, Kailasapathy, Kraimer, and Metz (2014) stated that leader-member exchange negatively related to work interference with family.

Besides that, scholars have examined the gender effect on work-life interaction. However, the results are inconsistent (Emslie \& Hunt, 2009). Moreover, most of these studies are based on a sample from Western countries, and Western understanding of the male and female role is different from other countries. For example, Sri Lanka, as a South Asian country, there is a clear difference of gender role among male and female. For instance, women are responsible for childcare, elder care, and managing household chores. Men are the family's breadwinner, mainly responsible for earning money and less engaging with household chores. Thus, the western understating of gender role might be different from culturally different economies. Thus, this study also attempts to understand how gender moderates the impact of work from home on work-life balance.

The rest of this paper is organized as follows. 'Literature review' section reviews the relevant literature on work-life balance and work from home research with the moderating effect of gender. The 'methods' section describes the methodology, and the 'results' section presents the results of data analysis. The final section discusses the findings, offers practical recommendations, acknowledges the limitations, and concludes this paper.

\section{LITERATURE REVIEW} 2.1 Spillover and Crossover Theory

Researchers have recognized crossover and spillover as two 
different ways family demands and work demands are carried over (as cited in Bakker \& Demerouti, 2009). Spillover is a within-person transmission of stress, strain, emotions, or experience that can be happened across domains that could be family and work domains (one particular area of life to another) (Bakker \& Demerouti, 2009). For example, an employee may have a conflict in spending time for his or her family role and work responsibilities, when work overload may cause cost in leisure hours. Prior studies (Amstad, Meier, Fasel, Elfering, \& Semmer, 2011; Bakker and Demerouti, 2009; Ford, Heinen, \& Langkamer, 2007) constantly report the spillover effect of work and family activities.

Westman (2001) defined crossover as the transmission of stress, strain, emotions, or experience from one person to another in a close relationship. Thus, job-related stress, strain, emotions experienced by an individual may lead to the strain being experienced by the individual's close relations. Thus, the spillover is an intra-individual transmission of stress, strain, emotions, and experience, while the crossover is an interindividual transmission of stressors (Bakker \& Demerouti, 2009).

\subsection{Work-Life border theory}

Work-life border theory was introduced by Clark (2000) as an extension of boundary theory. The theory stated that individuals create and maintain boundaries to simplify and order the environment demands (Ashforth et al., 2000, p.474). Moreover, the theory discusses the domain, the borders between work and home, the border crosses, and border keepers as central concepts. The domains include the work domain and family domain; individuals have different expectations and objectives to achieve in different domains. Besides, individuals keep borders between work and family, including physical, temporal, and psychological borders. However, people cross the border between work and family when they have a home office (work from home), they have the flexibility of arranging their work schedules, and they discuss work issues with family vis-à-vis.

\subsection{Work-Life balance}

An individual will never feel truly satisfied by his/her paid work/employment until he/she is satisfied by his personal life. Consequently, the individuals, be moderate in managing the work and non-work domains to enjoy life. Balance is not better time management but boundary management. It depicts how the individuals make choices and provide their time and involvement according to their priorities at a satisfactory level between these two domains. The employees should not confuse having a career or paid work with having a personal life. The individuals and the organizations intensely concentrate on the 
balanced life of the employees to create a productive and healthy work culture or the employees who can perform in all the domains. Work itself is not the whole life. Employees should balance all the domains, and organizations should provide proper working arrangements and schedules to the employees to have a balanced life.

Generally, work is known as the paid employment or the job of a person. The activities performed outside the work are known as life (Weerasinghe \& Jayawardana, 2019). Since work-life balance is a broad concept, it is defined differently using the diverse dimensions by different researchers. Scholars (Adisa, Gbadamosi \& Osabutey, 2017; Clark, 2000; Emslie \& Hunt, 2009; Helmle, Botero \& Seibold 2014; Poulose \& Sudarshan, 2014; Saltzstein, Ting and Saltzstein, 2001; Semali \& Hassi, 2016; Weerasinghe \& Jayawardana, 2019) described the "balance" as avoiding the conflict entirely with the satisfaction and smooth functioning at both the work and home.

Greenhaus, Collins, and Shaw (2003) defined work-life balance as the extent to which an individual is equally engaged inand equally satisfied with-his or her work role and family role.

Thus, work-life and personal life are two different dimensions: interconnected and interdependent and difficult to combine. Engaging more time with the paid work can interfere and make impacts on personal life.
Meanwhile, personal life commitments may impact worklife (Mohan, Prabha \& Mohanraj, 2010). The physical, temporal, and psychological boundary between work and home activities become unclear when work and home activities have an exact physical place (Basile \& Beaureguard, 2016). The worklife imbalance can happen in two ways; family-to-work conflict and work-to-family conflict, as the interference can happen in both directions (Beham \& Drobnič, 2010; Driscoll et al., 2004; Mostafa 2020).

Managing work and the rest of life is about spending more time with family commitments or reducing working hours, or working less than earlier. It depicts the minimum level of conflicts when employees perform the roles that are interconnected themselves. Though work from home is associated with some positive impacts, the employees are affected negatively as it presents a unique challenge and barrier to managing the boundaries between work and family life. Valcour (2007) stated that balancing family and work is a significant challenge faced by employees and employers (as cited in Adisa et al., 2017). Further, all the individuals try to maintain good family-related and work-related images to avoid an imbalance between personal and job roles.

\subsection{Work from Home}

In recent years, flexible work arrangements are considered an essential factor that helps to gain 
positive outcomes for the employees and the organizations (Choo et al., 2016).

When employees have the freedom to schedule and make changes on when, where (in which work), and the total time (how much one works) spend on their work-related tasks and duties, that helps increase the satisfaction. Successful implementation of flexible working policies or arrangements is needed to build a supportive and advantageous working environment (Mohan et al., 2010).

According to Hill et al. (2008), flexible work policies have become common practice within organizations. Organizations used different human resource strategies to attract, motivate and retain skilled employees to achieve the organization's targeted goals and personal objectives related to the job they did (as cited Choo et al. 2016).

There are three most essential arrangements of flexible working policy to the employees who need a Flexi arrangement and are eligible by the nature of their task and duties; flexibility in working hours, the location of the workplace, and the total time engaging with the paid work. There are common flexible work arrangements such as flex-time, compressed workweek, flexible working hours, shift swaps and job sharing, reduced hours, extra vacation, personal days, annualized hours, and long -term time off (Choo et al., 2016; Oludayo et al., 2019; Swaty \& Pahwa, 2020).
Though the several flexible work arrangements introduced by the entities to make efficiency and effectiveness in the employees' job performance and achieve planned organizational goals, home-based teleworking/work from home (WFH) has increasingly become a priority during the Pandemic situation. Businesses and employers are in a critical situation to decide the prevention and slow spread of Covid-19 within the office environment. Thus, considering the suitability of the job, whether it can be done at home or not, the employees are advised to perform their job at their residence by using advanced communication technologies because the employers have no alternative arrangements to provide a safe environment.

Work from home is often used synonymously with various other terms; home-based working, telework, telecommuting, virtual work at home, and remote work. Jachson (1999) and Kurland and Bailey (1999) described telework as home-based paid working, satellite office, neighborhood work center, and mobile telework (for more review see; Morganson, Major, Oborn, Verive \& Heelan, 2010; Tietze \& Musson, 2003). Telecommuting or telework can be facilitated under the flexible working policy to get work done (Baruch, 2000).

Giving a commonly accepted definition to the telework is difficult as it is a broad and complex phenomenon (Nakrošienè, Bučiūniencè \& 
Goštautaitè, 2019). Work from home/ home-based teleworking is described as performing the jobrelated job-related work at home rather than personal and household activities (Song \& Gao, 2018). According to Nakrošienė et al. (2019), works are getting entirely done from home, where a work agreement exists between the employee who is eligible for working from home by their job nature, and the specific employer is known as work from home.

Although the work from home is implemented to gain positive outcomes (Baruch, 2000; Harpaz, 2002; Tietze \& Musson, 2003), research has found that there are some negative consequences of work from home such as isolation, career harm, job insecurity, long work hour, and co-worker resentment (Green, 2019; Harpaz, 2002; Tietze \& Musson, 2003).

Work from home can create some challenges for managers, such as difficulty controlling and motivating telecommuters, less committed employees, losing team-working benefits, and team cohesiveness (Baruch, 2000). Researchers found in plenty of studies that the major issue of the work from home is no clearly defined limit or boundary between work and non-work tasks and personal and professional time, which is the root cause of all the issues (Harpaz,2002).

\subsection{Hypotheses development}

During the Covid-19 pandemic period, there is no comfort and safe structure other than the own residence or home of the employees to carry out organizational tasks. Thus, the organizations provide opportunities to work from home to get things done and maintain flow in the business process and services. It has led to more and more employees working from home. Earlier work from home was very rare among organizations, and now it has changed as necessity implementation in the crisis time. Though home-based working has potential benefits to employees and organizations, both face many challenges with that (Song \& Gao, 2018). If an employee works under normal circumstances, like going to work and coming home, there will be a clear physical space between work and home. Moreover, it makes a space between work and family roles and it helps to make less psychological attachment. In contrast, if there are no clear boundaries, family members believe that an employee working at home is constantly available for getting done home-related works. Hence, the blurred line between work and home is considered a top issue that can create conflict between work and family. Moreover, as work-family border theory (Clark, 2000) explained, borders between work and family are permeable, which is more severe when employees work from home. For instance, when an employee works from home, family members can enter the office and interact with the employee, disturbing the 
employee to perform the job. Moreover, as spillover theory proposed (Westman, 2001) stress or strain can transfer from one domain to another. However, this is more robust when employee work from home as no clear borders between work and life. Besides, crossover theory proposed transmission of stress or strain from one person to another in a close relationship. We believe, this is stronger when people are at the same place.

Thus, we proposed that; $H 1=$ There is a significant impact of work from home on work-life balance.

Gender differences and genderrelated issues in teleworking have been ambiguous and uncertain. Several researchers (Higgins, Duxbury, \& Lee, 1994; Peeters, Montgomery, Bakker \& Schaufeli, 2005; Simon,1995; Williams, 2000) found that worklife balance varies across gender. According to Belanger (1999) and Mokhtarian, Bagley, and Salomon (1998), work from home has been valued more by women than men as telework helps women to take care of their household and children. Mokhtarian et al. (1998) mentioned that women perceive more advantages than men when performing organizational tasks and duties from home. Chapman, Sheehy, and Heywood (1995) found that women have been motivated by flexibility and autonomy when working from home. Since not having a better idea to segregate personal and professional time, men and women who work from home become more involved in household issues than paid work activities. Extant literature on gender role expectations proposed that men and women experience work and family demands in different ways (Peeters et al., 2005). Hofacker and Konig's (2013) found that dealing with the work arrangements is different from men to women.

Moreover, scholars (deLay, Ayman, \& LoVerde, 1997; Fast \& Frederick, 1996;

Frenkenhaeuser et al., 1989; Kohler, Moran, \& Tansey, 1988; Lundberg, Mardberg, \& Frenkenhaeuser, 1994) found that women perform more non-work tasks than the men while working from home. Thus, work from home can create a great er degree of conflicts, making women more stressed than men while telecommuting than working usual working hours at a traditional office. Therefore, female telecommuters will perceive higher levels of difficulties in balancing work and family than male counterparts because of the unequal burden of the family responsibilities. Further, Huws, Korte, and Robinson (1990) found that women telecommuters feel socially isolated than men.

In contrast, scholars (Eagle, Miles \& Icenogle, 1997; Emslie, Hunt, \& Macintyre, 2004; Hughes \& Galinsky, 1994; Swanson, Power, \& Simpson, 1998; Triplett, Mullings, \& Scarborough, 1999; Winslow 2005) found that men and women experience a similar 
level of conflict when working from home.

Thus, we proposed that:

$H 2$ = The relationship between work from home on work-life balance will be significantly moderated by gender, such that the negative relationships are strengthened for the females.

The proposed conceptual framework is shown in figure 1 .

\section{METHODS}

\subsection{Sample and Procedures}

To test the hypotheses collected data from employees who are working from home during the covid-19 pandemic. The respondents were selected via the LinkedIn network, and we distributed around 400 survey invitations. As there was no systematic way to identify employees working from home and private sector companies, we included two screening questions to screen out non-qualified respondents. Only 350 were sent back the completed survey. Out of these respondents, 49 responses were discarded by the researcher since the respondents are not working from home (16 responses), and some respondents are regular workers working from home (33 responses). Thus, we used only 301 respondents for testing hypotheses.

\subsection{Measures}

3.2.1 Dependent Variable Work-Life Balance

Work-life balance was measured by using four items scale developed by Brough $e t$ al. (2014). The anchor points range from strongly disagree (01) to strongly agree (05). The example items are "I currently have a good balance between the time I spend at work and the time I have available for non-work activities" and "I feel that the balance between my work demands and non-work activities is currently about right."

3.2.2 Independent Variable Work from home

Work from home is measured using a standard measurement scale developed by Lucas (Macquarie University and the University of Technology, Sydney). We asked survey participants, "On average, how many days per week do you work from home?" and "On average, how many hours per day do you work from home?".

Further, in line with prior research, the researcher investigated fundamental individual factors (demographics and anticipatory factors).

\section{DATA ANALYSES AND RESULTS}

Before testing hypotheses, tests for missing data, outliers were carried out. Therefore, a frequency analysis for the Likert scale items in the questionnaire to check whether there are missing values in the data set and the researcher could ensure that the data is entered within the range correctly. The data were subsequently screened for univariate outliers using box plots. There were no univariate outliers found in the data set. 
We used simple linear regression to test our hypotheses. Further, the mean, standard deviation, and correlation coefficient are reported in Table 1.

\subsection{Hypotheses Testing}

In hypothesis 1 , we propose that there is a significant impact of work from home on work-life balance. As we proposed, the impact of work from home was significant $(\beta=-0.709, \mathrm{t}=-17.4, \mathrm{p}$ $=0.000)$ Thus, H1 is accepted. The model also explained a significant variance $(\mathrm{R} 2=0.503$ $(50.3 \%), \mathrm{p}=0.000)$.

In $\mathrm{H} 2$, we proposed that the relationship between work from home on work-life balance will be significantly moderated by gender. The results show that, $(\beta=$ $-0.020, p=0.906)$. According to that, the sig value $(0.906)$ is greater than 0.05 . Therefore, statistically claiming that, Gender is not a significant moderator for the relationship between Work from Home on Work- Life Balance. Thus, $\mathrm{H} 2$ is rejected (Results are shown in Table 4).

Further, the researcher uses Andrew F. Hayes process for SPSS (2018) as well to examine the moderator effect of gender on the relationship. According to the Andrew F. Hayes process for SPSS (2018), if the moderator is significant, zero (0) should not be in between lower and upper coefficient intervals, both values must be positive or negative. However, the results showed that $\beta=-0.0016$, s.e. $=0.0134, \mathrm{t}=-$ $0.1178, \mathrm{p}=0.9063 ; 95 \%$ CI $[-$
0.0279 to 0.0248$])$. As zero $(0)$ is between the lower coefficient interval and upper coefficient interval, the moderator (gender) is not significant (results are shown in table 5 and table 6). Therefore, the hypothesis two (H2) is rejected statistically claiming that, gender is not a significant moderator for the relationship between work from home on work- life balance.

\section{DISCUSSION}

The findings through analysis of data led to the discussion on the study. In the current study, the researchers found that there is a significant impact of work from home on the work-life balance of the employees, and gender is not a significant moderator of that relationship. Irrespective of contextual differences, the results are in line with and supported by some previous research studies. For example, Green (2019), Harpaz (2002), Irawanto, Novianti, \& Roz (2021) and Tietze and Musson (2003) found that there are negative consequences of home-based working. Thus, the finding of this study that there is a significant impact of Work from Home on Work-Life Balance, are consistent with prior studies.

Further, according to Peeters et al. (2005), gender may represent an important moderating variable of the work-home interference process. However, the findings of this study showed there is no gender effect on the relationship 
between work from home and work-life balance.

These findings are consistent with prior studies such as Eagle $e t$ al. (1997), Emslie et al. (2004), Hughes and Galinsky (1994), Swanson et al. (1998), Triplett et al. (1999), and Winslow (2005), who found men and women experience a similar level of conflict when working from home (Karkoulian et al., 2016).

\section{CONCLUSION}

The current study draws attention to the under-researched domains of work from Home and WorkLife Balance in the Sri Lanka context. The study's main objective was to examine the impact of work from Home on Work-Life Balance and moderating effect of gender among workers. The study's findings demonstrate that there is a significant and negative impact of work from Home on Work-Life Balance of the employees who started to practice the work from home during the pandemic period, and gender was not a significant determinant of work-life balance. Considering the findings of the current study, this study concludes by declaring that employees who started to practice work from home face so many challenges in balancing work and family life when their work-related tasks and duties are performed at their home of gender differences. Even though, the Work from Home has introduced to bring flexibility in performing tasks and duties, it brought so many negative consequences among the employees in balancing work and non-work activities during the pandemic. To overcome this situation the researcher, recommends to be followed to gain the expected benefits from the Work from Home concept. When introducing this concept, the organizations and their mangers should have the strong purpose like, the organizations should be committed to supporting Work from Home concept, provided that the needs and objectives of both the organization and the employee can be met, and the employees' deliverables are not disrupted in any form or manner and While not all positions are agreeable and suitable to Work from Home concept, consideration of Work from Home arrangements should be reviewed on a case-by-case basis - taking into account employee's tenure and the nature of the job role.

While it is crucial to continue business operations and strive towards achieving organizational goals and objectives, the organizations should understand that working from home continuously over a long period of time may cause mental fatigue (due to home and technology infrastructure, distraction by family, change in normal routines due to the crisis etc.) and negatively impact productivity levels of employees. Accordingly, the managers or employers should encourage their employees to use the effective practices regarding the working hours, work space, tasks and duties to be performed 
and collaboration platform where the employer or the manager should get the full concern and idea of employees' demographic factors; Gender, Age, Civil Status and House Hold Members' details to manage time better and work effectively to achieve success during prevailing pandemic. Moreover, the performance of the employees when working from home, as always, should be evaluated as per usual performance management processes and delivering on goals and KPIs. Finally, considering all the above-mentioned recommendations, document of the guidelines should be prepared and communicated among employees to support the employees and their respective line managers to navigate work responsibilities while staying safe and resilient during prevailing pandemic conditions with the purpose of managing Work from Home effectively, whilst optimizing productivity. 


\section{APPENDIX}

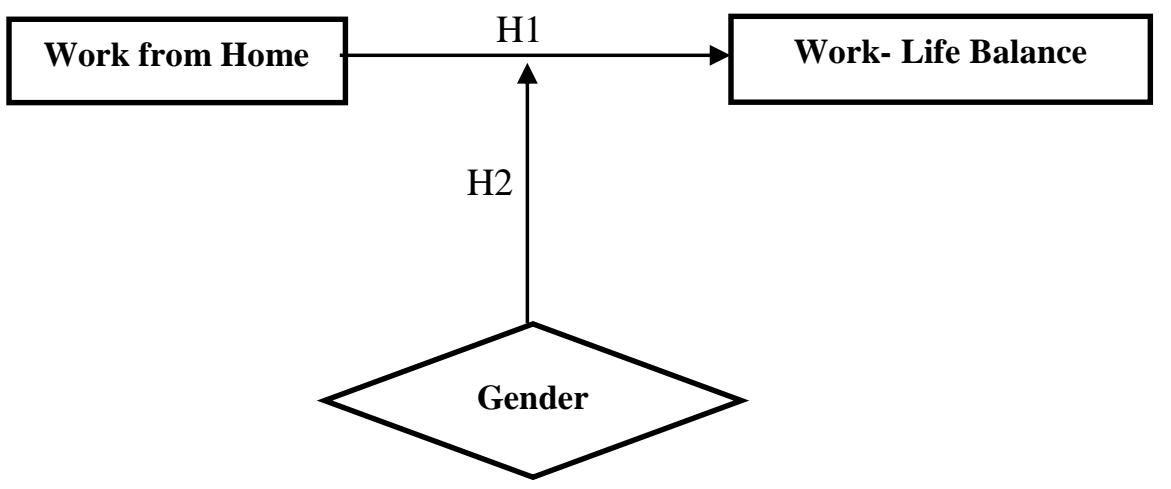

Figure 1: Conceptual Framework

Table 1: Result of Correlation Analysis, Mean, Standard Deviation

\begin{tabular}{|l|l|l|l|l|l|l|l|l|l|}
\hline No & Variable & $\mathbf{M}$ & SD & $\mathbf{1}$ & $\mathbf{2}$ & $\mathbf{3}$ & $\mathbf{4}$ & $\mathbf{5}$ & $\mathbf{6}$ \\
\hline $\mathbf{1}$ & Gender & 1.61 & .49 & & & & & & \\
\hline $\mathbf{2}$ & Age & 2.03 & .96 & $.22^{* *}$ & & & & & \\
\hline $\mathbf{3}$ & $\begin{array}{l}\text { Marital } \\
\text { Status }\end{array}$ & 1.56 & .50 & $.24^{* *}$ & $.77^{* *}$ & & &. & \\
\hline $\mathbf{4}$ & $\begin{array}{l}\text { Household } \\
\text { Members }\end{array}$ & 4.36 & .86 & $.14^{*}$ & $.30^{* *}$ & $.20^{* *}$ & & & \\
\hline $\mathbf{5}$ & Children & 2.53 & 1.45 & $.24^{* *}$ & $.56^{* *}$ & $.65^{* *}$ & $.47^{* *}$ & & \\
\hline $\mathbf{6}$ & $\begin{array}{l}\text { Work from } \\
\text { Home }\end{array}$ & 16.73 & 6.59 & $.14^{*}$ & $.38^{* *}$ & $.39^{* *}$ & $.301^{* *}$ & $.33^{* *}$ & \\
\hline $\mathbf{7}$ & $\begin{array}{l}\text { Work-Life } \\
\text { Balance }\end{array}$ & 2.19 & 1.14 & $-.35^{* *}$ & $-.42^{* *}$ & $-.45^{* *}$ & $-.45^{* *}$ & $-.49^{* *}$ & $-.71^{* *}$ \\
\hline
\end{tabular}

Note: $\mathrm{N}=301, \mathrm{M}=$ Mean , $\mathrm{SD}=$ Standard Deviation

Source: Analyzed Data (2021)

Table 2: Regression Statistics

\begin{tabular}{|l|l|}
\hline Multiple R & $.709^{\mathrm{a}}$ \\
\hline R Square & $.503(50.3 \%)$ \\
\hline Adjusted R Square & .501 \\
\hline Std. Error of the Estimate & .80217 \\
\hline F & 302.104 \\
\hline Sig. & $.000^{\mathrm{b}}$ \\
\hline Regression & Linear \\
\hline Method & Enter \\
\hline
\end{tabular}

Source: Analyzed Data (2021) 
Table 3: Coefficients ${ }^{\mathrm{a}}$ - Work from Home Impacts on Work-Life Balance

\begin{tabular}{|c|c|c|c|c|c|c|}
\hline \multicolumn{2}{|c|}{ Model } & \multicolumn{2}{|c|}{$\begin{array}{l}\text { Unstandardized } \\
\text { Coefficients }\end{array}$} & \multirow{2}{*}{$\begin{array}{l}\text { Standardized } \\
\text { Coefficients } \\
\text { Beta }\end{array}$} & \multirow[t]{2}{*}{$\mathrm{t}$} & \multirow[t]{2}{*}{ Sig. } \\
\hline & & $\mathrm{B}$ & Std. Error & & & \\
\hline \multirow[t]{2}{*}{1} & (Constant) & 4.232 & .126 & & 33.48 & .000 \\
\hline & Work from Home & -.122 & .007 & -.709 & -17.38 & .000 \\
\hline
\end{tabular}

Source: Analyzed Data (2021)

Table 4: Results of Linear Regression Analysis of Moderator

\begin{tabular}{|l|c|c|c|}
\hline \multicolumn{1}{|c|}{ Variables } & Model 1 & Model 2 & Model 3 \\
\hline Work from Home & $-.709(.000)$ & $-.673(.000)$ & $-.659(.000)$ \\
\hline Gender & & $-.255(.000)$ & $-.244(.018)$ \\
\hline Interaction & & & $-.020(.906)$ \\
Work from home x gender & & & .014 \\
\hline$\Delta F$ & 302.104 & 43.689 & .000 \\
\hline$\Delta R^{2}$ & .503 & .064 & 129.217 \\
\hline Equation $F$ & 302.104 & 194.462 & .562 \\
\hline Equation adjusted $R^{2}$ & .501 & .563 & \\
\hline
\end{tabular}

$* n=301$; Standardized coefficients are reported.

Source: Analyzed Data (2021)

Table 5: Results of Process for SPSS (Model Summary)

\begin{tabular}{|c|c|c|c|c|c|c|}
\hline \multicolumn{1}{|l|}{ Model Summary } \\
\hline $\mathrm{R}$ & $\mathrm{R}-\mathrm{sq}$ & MSE & $\mathrm{F}$ & $\mathrm{df1}$ & $\mathrm{df2}$ & $\mathrm{p}$ \\
.7525 &. & .5650 & 129.21 & 3.0000 & 297.00 & .0000 \\
& 5662 & & 72 & & 00 & \\
\hline
\end{tabular}

Source: Analyzed Data (2021)

Table 6: Results of Process for SPSS (Model)

\begin{tabular}{|l|c|c|c|c|c|c|}
\hline & coeff & se & $\mathrm{T}$ & $\mathrm{p}$ & LLCI & ULCI \\
\hline Constant & 5.0397 & 0.3782 & 13.3262 & .0000 & 4.2955 & 5.7840 \\
WFH & -0.1136 & 0.0218 & -5.2005 & .0000 & -0.1566 & -0.0706 \\
Gender & -0.5656 & 0.2374 & -2.3820 & .0178 & -1.0328 & -0.0983 \\
Int_1 & -0.0016 & 0.0134 & -0.1178 & .9063 & -0.0279 & 0.0248 \\
& & & & & & \\
\hline
\end{tabular}

Product terms key:

Int_1: WFH $\quad$ X Gender

Source: Analyzed Data (2021) 


\section{REFERENCES}

Adisa, T. A., Gbadamosi, G., \& Osabutey, E. L. (2017). The role of mobile information technology devices on employees' work-life balance. Personnel Review, 46 (8): 1651-1671.

Bakker, A. B., \& Demerouti, E. (2009). The crossover of work engagement between working couples: A closer look at the role of empathy. Journal of Managerial Psychology, 24(3):220-236.

Baruch, Y. (2000). Teleworking: benefits and pitfalls as perceived by professionals and managers.

Basile, K. A., \& Beauregard, T. A. (2016). Strategies for successful telework: how effective employees manage work/home boundaries. Strategic HR Review, 15(3):106-111.

Beham, B., \& Drobnic, S. (2010). Satisfaction with workfamily balance. Journal of Managerial Psychology, 25(6): 669-689.

Brough, P., Timms, C., Driscoll, M., Kalliath, T., Siu, O.-L., Sit, C., \& Lo, D. (2014). Work-Life Balance. The International Journal of Human Resource Management, 25:2724 2744.

Choo, J. L., Desa, N. M., \& Asaari, M. A. (2016). Flexible working arrangement toward organizational commitment and work-family conflict. Studies in Asian Social Science, 03(1).

Clark, S.C. (2000). Work/family border theory: A new theory of work-life balance. Human Relations, 53(6): 7470-7770.

Darcy, C., \& McCarthy, A. (2007). Work-family conflict. Journal of European Industrial Training, 31(7): 530-549.

Driscoll, M., Brough, P., \& Kalliath, T. (2004). Work/Family Conflict, Psychological Well-Being, Satisfaction, and Social Support. Journal of Equal Opportunities, 23 (1-2):3656.

Emslie, C., \& Hunt, K. (2009). Live to Work or Work to Live. Gender, Work, and Organizations, 16 (1):151172.

Green, C. (2019). Examining the effects of negative work outcomes on Telecommuting. Poster published by Middle Tennessee state University.

Greenhaus, J., Collins, K., \& Shaw, J. (2003). The relation between workfamily balance and quality of life. Journal of Vocational Behavior, 63:510 - 531.

Harpaz, I. (2002). Advantages and Disadvantages of telecommuting. WorkStudy, 51(2):74-80.

Humphries, N. McDermott, A.M., Creese,J., Matthews, A., Conway, E., Byrne, J-P. 
(2020). Hospital doctors in Ireland and the struggle for work-life balance.

European Journal of Public Health, 30 (4): 32-35.

Irawanto, D.W., Khusnul R.N., \& Roz, K. (2021). Work from Home: Measuring Satisfaction between Work-Life Balance and Work Stress during the COVID-19 Pandemic in Indonesia. Economies 9(96):1-13.

Kailasapathy, P., Kraimer, M., \& Metz, M. (2014). The interactive effects of leader-member exchange, gender and spouse's gender role orientation on work interference, with workfamily conflict. International Journal of Human Resource Management, 25: 26812701.

Koon, V-Y. (2020). A multilevel analysis of work-life balance practices. Asia Pacific Journal of Human Resources. (in press).

Lazarova, M., Westman, M., \& Shaffer, M. A. (2010). Elucidating the positive side of the work-family interface on international assignments: A model of work and family performance. Academy of Management Review, 35(1): 93-117.

Lucas, G. (n.d.). Employees Working from Home.

Mohan, N., Prabha, N., \& Mohanraj, P. (2010). Work- life balance through Flexi work

arrangement. International Journal of Management, 1(2):53-61.

Morganson, V., Major, D., Oborn, K., Verive, J., \& Heelan, M. (2010). Comparing telework locations and traditional work arrangements. Journal of Managerial Psychology, 25(6):578-595.

Mostafa, A. S. (2020). Workfamily conflict, negative affect, and psychosomatic health complaints. International Journal of Organizational Analysis, 28(4):831-842.

Nakrošienė, A., Bučiūniencè , I., \& Goštautaitè, B. (2019). Working from home. International

Journal of Manpower, 40(1):87-101.

Nilashini, W.T.A., \& Sajeevanie, T.L. (2018). Relationship between Organizational Work Life Balance Factors and Executive Employee's Performance in Selected IT Organizations in Sri Lanka. Sri Lankan Journal of Human Resource Management 8(1):60-76.

Oludayo, O., Salau, O., Falola, H., Atolagbe, T., Ogueyungbo, A., \& Fatogun, T. (2019). Flexible work arrangement initiatives and commitment outcome of the selectedtechnology. Interna tional Journal of 
Mechanical Engineering and Technology, 10(3):161171.

Peeters, M. C., Montgomery, A. J., Bakker, A. B., \& Schaufeli, W. B. (2005). Balancing Work and Home; How Job and Home Demands are related to Burnout. International

Journal of Stress
Management, 12:43 - 61.

Poulose, S., \& Sudarshan, N. (2014). Work-Life Balance: A conceptual

Review. International Journal of Advances in Management and Economics, 03(2):01-17.

Sanchez, A. M., Perez, M. P., Jimenz, M. V., \& Garces, S. A. (2018). Job satisfaction and work-family policies through work-family enrichment. Journal of Managerial Psychology, 33(4-5):386-402.

Song, Y., \& Gao, J. (2018). Teleworks Stresses Employees out: Study on Working at Home and Subjective Well-Being for Wage/ Salary Workers. Journal of Happiness Studies, 21:2649-2668.
Swaty, \& Pahwa, S. (2020). Flexible working. UGC Care Journal, 251-258.

Tietze, S. (2005). Discourse as a strategic coping resource: Managing the interface between home and work. Journal of Organizational Change Management, 18(1):48-62.

Tietze, S., \& Musson, G. (2003). The times and temporalities of home-based telework. Personnel Review, 32(4):438-455.

Weerasinghe, T., \& Jayawardana, A. (2019). Flex-Work and Work-Life Balance: Effects of Role Conflicts and Work-Life Support Organizational Culture. Sri Lankan Journal of Management, 24(21): 4008-4025.

Westman, M. (2001). Stress and strain crossover, Human Relations, 54(6):557-91.

Westman, M. \& Vinokur, A. (1998). Unraveling the relationship of distress levels within couples: Common stressors, emphatic reactions, or crossover via social interactions? Human Relations, 51:137-56. 